\title{
Novel Method for the Preparation of Metal Cyclopropenyl Complexes from Vinylidene Complexes with an Electron-Withdrawing Substituent
}

\author{
Pei-Chen Ting, Ying-Chih Lin," Ming-Chu Cheng, and Yu Wang \\ Department of Chemistry, National Taiwan University, \\ Taipei, Taiwan 10764, Republic of China
}

Received February 22, $1994^{\star}$

Summary: Deprotonation of the cationic vinylidene complex $\left[\mathrm{Cp}\left(\mathrm{PPh}_{3}\right)_{2} \mathrm{Ru}=\mathrm{C}=\mathrm{C}(\mathrm{Ph}) \mathrm{CH}_{2} \mathrm{CN}\right] I(2 \mathrm{2})$ by $(n-$ $B u{ }_{4} N F$ yields the neutral cyclopropenyl complex $C p$ $\left(P P h_{3}\right)_{2} R u-C=C(P h) C H C N(3 a)$. For $C p\left(P P h_{3}\right)_{2} R u=$ $\left.\mathrm{C}=\mathrm{C}(\mathrm{Ph}) \mathrm{CH}_{2} \mathrm{OCH}_{3}\right] \mathrm{I}(2 \mathrm{~b})$ the fluoride attacks $\mathrm{C}_{\alpha}$ to produce the vinyl complex $C p\left(P P h_{3}\right)_{2} R u-C(F)=C(P h)-$ $\mathrm{CH}_{2} \mathrm{OCH}_{3}(4)$. Electrophilic attack at the methyne carbon of $3 \mathrm{a}$ by $\mathrm{H}^{+}$or $\mathrm{Ph}_{3} \mathrm{C}^{+}$opens the three-membered ring and gives back the vinylidene complexes.

Metal vinylidene complexes have attracted a great deal of attention in recent years. Extensive reviews have appeared recently. ${ }^{1} \mathrm{~A}$ theoretical study of vinylidene complexes associated the localization of electron density on $\mathrm{C}_{\beta}$ (HOMO) or in the $\mathrm{M}=\mathrm{C}$ double bond and the electron deficiency at $\mathrm{C}_{\alpha}{ }^{2}$ Thus, protonation of the vinylidene ligand at $\mathrm{C}_{\beta}$ to form a carbyne occurs readily unless the ligand is present in a cationic complex. With a more electron rich metal center, addition to the $\mathrm{M}=\mathrm{C}$ bond gives $\left(\eta^{2}\right.$-allene)- or (heteroketene) metal complexes. Intramolecular attack of the acetylide $\mathrm{C}_{\beta}$ at a pendant terminal alkyl halide chain also gives cyclic vinylidene complexes. ${ }^{1 \mathrm{c}}$ On the other hand, addition of the acetylenic alcohols $\mathrm{HC} \equiv \mathrm{C}\left(\mathrm{CH}_{2}\right)_{x} \mathrm{OH}$ to $\mathrm{CpRuL}_{2} \mathrm{Cl}$ afforded cyclic carbene complexes. The reaction proceeds via initial formation of the vinylidene complexes, followed by an intramolecular attack of the terminal alcohol function at $\mathrm{C}_{\alpha} \cdot{ }^{3}$ A study of the reaction of alcohols with $\mathrm{Ru}$ vinylidene complexes indicated that the electron-withdrawing groups on the acetylide unit or on the metal facilitate nucleophilic attack at $\mathrm{C}_{\alpha}{ }^{4}$ For the reactions of vinylidene complexes with diazomethane, various addition modes have been revealed. ${ }^{5}$ Utilizing the above-mentioned reactivities, herein we report a novel cyclopropenation reaction by appending an electron-withdrawing substituent to $\mathrm{C}_{\gamma}$ of the vinylidene ligand.

Reaction of $\mathrm{Cp}\left(\mathrm{PPh}_{3}\right)_{2} \mathrm{RuC} \equiv \mathrm{CPh}$ (1) with $\mathrm{ICH}_{2} \mathrm{CN}$ gives the cationic vinylidene complex $\left[\mathrm{Cp}\left(\mathrm{PPh}_{3}\right)_{2} \mathrm{Ru}=\right.$ $\left.\mathrm{C}=\mathrm{C}(\mathrm{Ph}) \mathrm{CH}_{2} \mathrm{CN}\right] \mathrm{I}(\mathbf{2 a})^{6}$ in $83 \%$ yield. The vinylidene ligand of $2 \mathrm{a}$ is confirmed by the presence of a triplet ${ }^{13} \mathrm{C}$

- Abstract published in Advance ACS Abstracts, May 15, 1994.

(1) (a) Bruce, M. I. Chem. Rev. 1991, 91, 197. (b) Bruce, M. I. Adv. Organomet. Chem. 1983, 22, 59. (c) Davies, S. G.; McNally, J. P.; Smallridge, A. J. Adv. Organomet. Chem. 1990, 30, 1.

(2) Kostic, N. M.; Fenske, R. F. Organometallics 1982, 1, 974.

(3) Bruce, M. I.; Swincer, A. G.; Thomson, B. J.; Wallis, R. C. Aust. J. Chem. 1980, 33, 2605.

(4) Bruce, M. I.; Swincer, A. G. Aust. J. Chem. 1980, 33, 1471

(5) (a) Hoel, E. L.; Ansell, G. B.; Leta, S. Organometallics 1984, 3, 1633. (b) Werner, W.; Wolf, J.; Muller, G.; Kruger, C. Angew. Chem. 1984, 96, 421. (c) Consiglio, G.; Schwab, R.; Morandini, F. J. Chem. Soc., Chem. Commun. 1988, 25.

(6) Spectroscopic data for $2 \mathrm{a}:{ }^{2} \mathrm{H}$ NMR $\left(25^{\circ} \mathrm{C}, \mathrm{CD}_{3} \mathrm{COCD}_{3}\right) \delta 8.16-$ $7.03(\mathrm{Ph}), 5.61(\mathrm{~s}, 5 \mathrm{H}, \mathrm{Cp}), 3.56\left(\mathrm{~s}, 2 \mathrm{H}, \mathrm{CH}_{2}\right) ;{ }^{13} \mathrm{C} \mathrm{NMR}\left(25{ }^{\circ} \mathrm{C}, \mathrm{CD}_{\mathrm{s}}\right.$ $\left.\mathrm{COCD}_{3}\right) \delta 345.6\left(\mathrm{t}, J_{\mathrm{P}-\mathrm{C}}=17.9 \mathrm{~Hz}, \mathrm{C} \alpha\right), 134.8-128.4(\mathrm{Ph}), 123.0\left(\mathrm{C}_{\beta}\right) 118.5$ (CN), $95.6(\mathrm{Cp}), 14.5\left(\mathrm{CH}_{2}\right) ;{ }^{31 P}$ NMR $\left(25^{\circ} \mathrm{C}, \mathrm{CDCl}_{3}\right) \delta 41.0$ (s); MS (FAB) $\mathrm{m} / \mathrm{z} 832\left(\mathrm{M}^{+}\right), 570\left(\mathrm{M}^{+}-\mathrm{PPh}_{3}\right), 429\left(\mathrm{M}^{+}-\mathrm{PPh}_{3}, \mathrm{C}_{2} \mathrm{PhCH}_{2} \mathrm{CN}\right)$.

\section{Scheme 1}

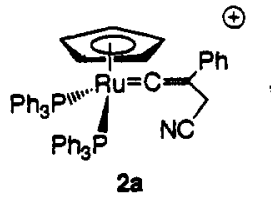

2a

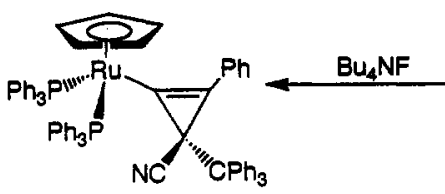

3d
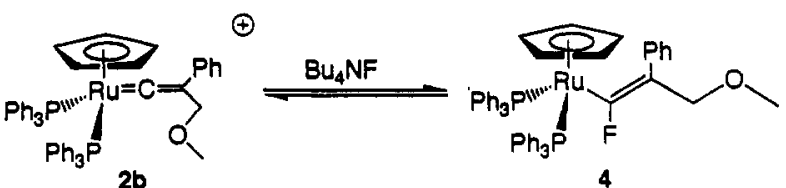

resonance with $J_{\mathrm{C}-\mathrm{P}}=17.9 \mathrm{~Hz}$ at $\delta 345.6$ assignable to $\mathrm{C}_{\alpha}$. Other spectroscopic data are consistent with this formulation. For example, in the ${ }^{31} \mathrm{P} \mathrm{NMR}$ spectra, the two $\mathrm{PPh}_{3}$ ligands give a single resonance due to the fluxional behavior of the vinylidene ligand (the alkylidene ligand of 2 , with two different substituents, is a two-dimensional chiral complex). Deprotonation of one of the methylene protons of $2 \mathrm{a}$ by $(n-\mathrm{Bu})_{4} \mathrm{NF}$ ( $1 \mathrm{M}$ in THF) cleanly yields the neutral

cyclopropenyl complex $\mathrm{Cp}\left(\mathrm{PPh}_{3}\right)_{2} \mathrm{Ru}-\mathrm{C}=\mathrm{C}(\mathrm{Ph}) \mathrm{CHCN}$ (3a; ${ }^{7}$ see Scheme 1). Complex $3 \mathbf{a}$ is a yellow, air-stable compound, soluble in $\mathrm{CHCl}_{3}$ or THF and insoluble in hexane or $\mathrm{CH}_{3} \mathrm{CN}$. When the reaction is carried out at low concentration, single crystals of complex $3 \mathrm{a}$ are directly obtained. The identification of $3 \mathrm{a}$ in solution was through ${ }^{31} \mathrm{P} N M R$, which gave the expected $A B$ spectrum at room temperature, because the chiral center created by the cyclization process thus makes the two phosphine ligands inequivalent. The molecular structure of compound $\mathbf{3 a}$ has been confirmed by a single-crystal X-ray diffraction study. ${ }^{8}$ The two optical isomers crystallized together. The

(7) Spectroscopic data for 3a: ${ }^{1} \mathrm{H}$ NMR $\left(25^{\circ} \mathrm{C}, \mathrm{CDCl}_{3}\right) \delta 7.20-6.61 \mathrm{(m}$ $35 \mathrm{H}, \mathrm{Ph}), 4.54(\mathrm{~s}, 5 \mathrm{H}, \mathrm{Cp}), 1.40(\mathrm{~s}, 1 \mathrm{H}, \mathrm{CH}) ;{ }^{13} \mathrm{C} \mathrm{NMR}\left(25^{\circ} \mathrm{C}, \mathrm{CDCl}_{3}\right) \delta$ $134.8-128.4(\mathrm{Ph}), 126.2\left(\mathrm{t}, J_{\mathrm{C}-\mathrm{P}}=23.0 \mathrm{~Hz}, \mathrm{C}_{\alpha}\right), 113.8(\mathrm{CN}), 86.3(\mathrm{Cp}), 7.96$ $(\mathrm{CH})$; ${ }^{31} \mathrm{P}$ NMR $\left(25^{\circ} \mathrm{C}, \mathrm{CDCl}_{3}\right) \delta 51.7,49.6\left(\mathrm{AB}, J_{\mathrm{P}-\mathrm{P}}=34.6 \mathrm{~Hz}\right) ; \mathrm{MS}$ (FAB) $m / z 831\left(\mathrm{M}^{+}\right), 570\left(\mathrm{M}^{+}-\mathrm{PPh}_{3}\right), 429\left(\mathrm{M}^{+}-\mathrm{PPh}_{3}, \mathrm{C}_{2} \mathrm{PhCH}_{2} \mathrm{CN}\right)$. 


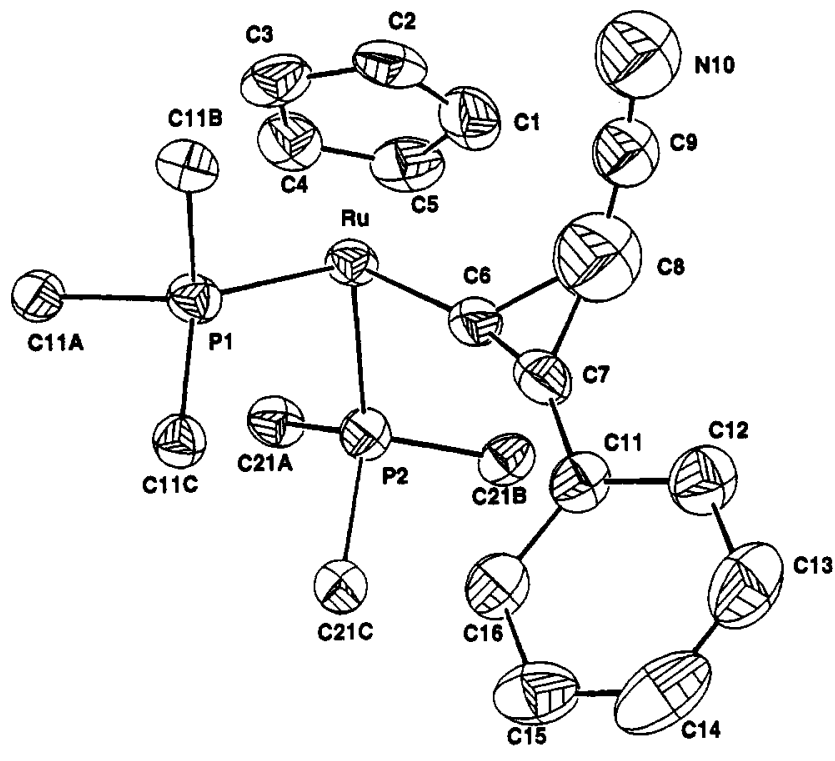

Figure 1. ORTEP drawing of $\mathrm{Cp}\left(\mathrm{PPh}_{3}\right)_{2} \mathrm{Ru}-\mathrm{C}=\mathrm{C}(\mathrm{Ph})$ CHCN (3a) with thermal ellipsoids shown at the $30 \%$ probability level. Phenyl groups on the two triphenylphosphine ligands are omitted for clarity. Selected bond distances $(\AA)$ and bond angles (deg) are as follows: $R u-P(1), 2.309(2)$; $\mathrm{Ru}-\mathrm{P}(2), 2.302(2) ; \mathrm{Ru}-\mathrm{C}(6), 2.034(5) ; \mathrm{C}(6)-\mathrm{C}(7), 1.289(8)$; $\mathrm{C}(6)-\mathrm{C}(8), 1.58(1) ; \mathrm{C}(7)-\mathrm{C}(8), 1.45(1) ; \mathrm{C}(8)-\mathrm{C}(9), 1.22(2)$; $\mathrm{C}(9)-\mathrm{N}(10), 1.10(2) \AA ; \mathrm{C}(6)-\mathrm{Ru}-\mathrm{P}(1), 89.9(2) ; \mathrm{C}(6)-\mathrm{Ru}-\mathrm{P}(2)$, 92.4(2); $\mathrm{Ru}-\mathrm{C}(6)-\mathrm{C}(7), 169.7(4)^{\circ} ; \mathrm{Ru}-\mathrm{C}(6)-\mathrm{C}(8), 130.4(4)^{\circ}$; $\mathrm{C}(8)-\mathrm{C}(6)-\mathrm{C}(7), 59.8(4)^{\circ} ; \mathrm{C}(6)-\mathrm{C}(7)-\mathrm{C}(8), 70.1(5)^{\circ} ; \mathrm{C}(6)-$ $\mathrm{C}(8)-\mathrm{C}(7), 50.1(4)^{\circ} ; \mathrm{C}(6)-\mathrm{C}(8)-\mathrm{C}(9), 135.5(8)^{\circ}$.

ORTEP diagram of one isomer is shown in Figure 1. The metal center is coordinated to an $\mathrm{sp}^{2}$ carbon of the substituted cyclopropenyl ligand. The $\mathrm{Ru}-\mathrm{C}(2)$ distance of $2.034(5) \AA$ is typical for a Ru-C single bond, and the $\mathrm{C}(6)-\mathrm{C}(7)$ distance of $1.289(8) \AA$ is typical of a carboncarbon double bond. The $\mathrm{Ru}-\mathrm{C}(6)-\mathrm{C}(7)$ bond angle is $169.7(4)^{\circ}$, far greater than the idealized $\mathrm{C}\left(\mathrm{sp}^{2}\right)$ hybridization bond angle, possibly due to the ring strain. Interestingly, the intermolecular nucleophilic attack of $\mathbf{2 a}$ is not attainable; i.e. in a mixture of $2 \mathrm{a}$ and $\mathrm{MeOH}$, no reaction was observed. A few transition-metal cyclopropenylidene complexes, mostly from dichlorocyclopropene, ${ }^{9}$ and a number of $\pi$-cyclopropene complexes ${ }^{10}$ are known. Metal cyclopropenyl derivatives in which the metal is bonded to the methylene $\mathrm{C}$ atom (in this case the ring can be viewed as an antiaromatic cyclopropenide ion) have been reported. ${ }^{11}$ However, to our knowledge there is only one

(8) Crystal data for $3 \mathrm{a}: \mathrm{C}_{51} \mathrm{H}_{40} \mathrm{P}_{2} \mathrm{NRu}$, space group $P 2_{1} / n, a=10.993$. (4) $\AA, b=17.385(9) \AA, c=21.276(5) \AA, \beta=101.45(3)^{\circ}, V=3985(3) \AA^{3}$, $Z=4, D_{\mathrm{c}}=1.383 \mathrm{~g} \mathrm{~cm}^{-3}, \mu=5.703 \mathrm{~cm}^{-1}, 4106$ observed reflections, $2 \theta_{\text {max }}$ $=45^{\circ}, R=0.040, R_{\mathrm{w}}=0.034 ;$ Mo K $\alpha$ radiation, $\lambda=0.70930 \AA, T=298$ $K$. Both optical isomers are observed, and the two $C N$ groups were refined with $50 \%$ occupancy.

(9) (a) Kirchgassner, U.; Piana, H.; Schubert, U. J. Am. Chem. Soc 1991, 113, 2228. (b) Miki, S.; Ohno, T.; Iwasaki, H.; Yoshida, Z.-I. J Phys. Org. Chem. 1988, 1, 333. (c) Yoshida, Z.-1. Pure Appl. Chem. 1982, $54,1059$.

(10) (a) Schrock, R R Acc. Chem, Res, 1986, 19, 342, (b) Hughes, R. P.; Reisch, J. W.; Rheingold, A. L. Organometallics 1985, 4, 1754 . (c) Hughes, R. P.; Cläui, W.; Reisch, J. W.; Müller, A.; Rheingold, A. L. Organometallics 1985, 4, 1761. (d) Mealli, C.; Midollini, S.; Moneti, S.; Sacconi, L. Silvestre, J. Albright, T. A. J. Am. Chem. Soc. 1982, 104, 59.

(11) (a) Löwe, C.; Shklover, V.; Bosch, H. W. Berke, H. Chem. Ber. 1993, 126, 1769. (b) Gompper, R.; Bartmann, E. Angew. Chem. 1978, 90 490. (c) DeSimone, D. M.; Desrosiers, P. J.; Hughes, R. P. J. Am. Chem. Soc. 1982, 104, 4842. (d) Hughes, R. P.; Donaldson, W. A. J. Am. Chem. Soc. 1982, 104, 4846. (e) Weiss, R.; Priesner, C. Angew. Chem. 1978, 90 491 . previous example ${ }^{12}$ in which the metal is bonded to $\mathrm{C}\left(\mathrm{sp}^{2}\right)$ of the three-membered ring.

A different pattern was observed for the reaction of the analogous dark red complex $\left[\mathrm{Cp}\left(\mathrm{PPh}_{3}\right)_{2} \mathrm{Ru}=\mathrm{C}=\mathrm{C}(\mathrm{Ph})\right.$ $\mathrm{CH}_{2} \mathrm{OCH}_{3}$ ]I (2b) ${ }^{13}$ with $(n-\mathrm{Bu})_{4} \mathrm{NF}$. The reaction produced the yellow metal vinyl complex $\mathrm{Cp}\left(\mathrm{PPh}_{3}\right)_{2} \mathrm{Ru}-\mathrm{C}$ $(\mathrm{F})=\mathrm{C}(\mathrm{Ph}) \mathrm{CH}_{2} \mathrm{OCH}_{3}$ (4). ${ }^{14}$ In this case about $75 \%$ conversion had been reached in acetone at $10^{\circ} \mathrm{C}$. Complex 4 is soluble only in $\mathrm{CHCl}_{3}$ and insoluble in most of the organic solvents. Upon dissolution complex 4 instantaneously reconverted to $2 b$ (with fluoride anion) at room temperature. Therefore, the spectroscopic data were obtained at $-40^{\circ} \mathrm{C}$. In the ${ }^{13} \mathrm{C} N M R$ spectrum of 4 , a doublet resonance $\left({ }^{3} J_{\mathrm{C}-\mathrm{F}}=21.8 \mathrm{~Hz}\right.$ ) at $\delta 70.8$ (which gives an inverted peak in a DEPT-135 experiment) is assigned to the methylene carbon. The coupling constant $J_{\mathrm{P}-\mathrm{F}}=$ $47 \mathrm{~Hz}$ of the doublet resonance at $\delta 50.2$ in the ${ }^{31} \mathrm{P}$ NMR spectrum is consistent with the triplet resonance in the ${ }^{19} \mathrm{~F}$ NMR spectrum. In the ${ }^{1} \mathrm{H}$ NMR spectrum, an exceptionally upfield $\mathrm{Cp}$ resonance at $\delta 3.78$ is ascribed to the presence of the electron-withdrawing fluoride substituent at the vinyl $\mathrm{C}_{\alpha}$. In an attempted reaction of $\left[\mathrm{Cp}\left(\mathrm{PPh}_{3}\right)_{2} \mathrm{Ru}=\mathrm{C}=\mathrm{C}(\mathrm{Ph}) \mathrm{CH}_{2} \mathrm{CH}=\mathrm{CH}_{2}\right] \mathrm{Br}$ (2c) with (n$\mathrm{Bu})_{4} \mathrm{NF}$, neither deprotonation nor nucleophilic attack was observed. The formations of $3 \mathbf{a}$ and 4 are thus attributed to the electron-withdrawing substituents at $\mathrm{C}_{\gamma}$. The CN group of $2 \mathrm{a}$ increases the acidity of the methylene protons and makes the deprotonation/cyclization reaction possible. On the other hand, the $\mathrm{CH}_{3} \mathrm{OCH}_{2}$ group of $\mathbf{2 b}$ makes $\mathrm{C}_{\alpha}$ more electrophilic for fluoride attack. The importance of ionic fluorides as proton abstractors in baseassisted reactions, ${ }^{15}$ and as sources of fluorine in the synthesis of organofluorine derivatives, ${ }^{16}$ is well documented. Attempts to deprotonate $2 \mathrm{a}$ by other bases were unsuccessful. There should be factors associated with the ionic fluoride (other than the basicity and nucleophilicity) that govern the reactions of $2 \mathrm{a}$ and/or $2 \mathrm{~b}$ with $(n-\mathrm{Bu})_{4} \mathrm{NF}$. These factors are not yet clear.

Protonation of $3 \mathrm{a}$ in $\mathrm{CH}_{3} \mathrm{CN}$ by $\mathrm{CF}_{3} \mathrm{COOH}$ immediately produces $2 \mathrm{a}$ in a quantitative yield. Conversion of 4 back to $\mathbf{2 b}$ is also a fast reaction. Reaction of $3 \mathbf{a}$ with $\mathrm{Ph}_{3} \mathrm{CPF}_{6}$ also affords $\left[\mathrm{Cp}\left(\mathrm{PPh}_{3}\right)_{2} \mathrm{Ru}=\mathrm{C}=\mathrm{C}(\mathrm{Ph}) \mathrm{CH}\left(\mathrm{CPh}_{3}\right) \mathrm{CN}\right] \mathrm{PF}_{6}$ (2d) ${ }^{17}$ in $65 \%$ yield. Trityl cation serves as an electrophile attacking the methyne carbon of the three-membered ring. Further deprotonation of the methyne proton of $\mathbf{2 d}$ by

(12) Gompper, R.; Bartmann, E. Angew. Chem. 1985, 97, 207.

(13) Spectroscopic data for $2 \mathrm{~b}$ : ${ }^{1} \mathrm{H}$ NMR $\left(25^{\circ} \mathrm{C}, \mathrm{CD}_{3} \mathrm{CN}\right) \delta 7.43-6.94$ $(\mathrm{Ph}), 5.32(\mathrm{~s}, 5 \mathrm{H}, \mathrm{Cp}), 3.95\left(\mathrm{~s}, 2 \mathrm{H}, \mathrm{CH}_{2}\right), 3.09\left(\mathrm{~s}, 3 \mathrm{H}, \mathrm{CH}_{3}\right) ;{ }^{13} \mathrm{C} \mathrm{NMR}(25$ $\left.{ }^{\circ} \mathrm{C}, \mathrm{CD}_{3} \mathrm{CN}\right) \delta 348.5\left(\mathrm{t}, J_{\mathrm{C}-\mathrm{P}}=16.1 \mathrm{~Hz}, \mathrm{C}_{\alpha}\right), 135.9-128.8(\mathrm{Ph}), 95.7(\mathrm{Cp})$, $67.5\left(\mathrm{CH}_{2}\right), 57.8\left(\mathrm{CH}_{3}\right) ;{ }^{31 \mathrm{P}} \mathrm{NMR}\left(25^{\circ} \mathrm{C}, \mathrm{CD}_{3} \mathrm{CN}\right) \delta 42.5(\mathrm{~s}) ; \mathrm{MS}$ (FAB) $m / z 837\left(\mathrm{M}^{+}\right), 575\left(\mathrm{M}^{+}-\mathrm{PPh}_{3}\right), 429\left(\mathrm{M}^{+}-\mathrm{PPh}_{\mathrm{g}}, \mathrm{C}_{2} \mathrm{PhCH}_{2} \mathrm{OMe}\right)$.

(14) Spectroscopic data for 4: ${ }^{1} \mathrm{H}$ NMR $\left(-40^{\circ} \mathrm{C}, \mathrm{CDCl}_{3}\right) \delta 7.47-6.88$ (Ph), 4.00 (br s, $2 \mathrm{H}, \mathrm{CH}_{2}$ ) $3.78(\mathrm{~s}, 5 \mathrm{H}, \mathrm{Cp}), 3.05$ (s, $\left.3 \mathrm{H}, \mathrm{CH}_{3}\right) ;{ }^{13} \mathrm{C}$ NMR $\left(-40^{\circ} \mathrm{C}, \mathrm{CDCl}_{3}\right), 133.4-125.8(\mathrm{Ph}), 84.3(\mathrm{Cp}), 70.8\left(\mathrm{~d}, J_{\mathrm{C}-\mathrm{F}}=21.8 \mathrm{~Hz}\right.$, $\left.\mathrm{CH}_{2}\right), 55.4\left(\mathrm{CH}_{3}\right) ;{ }^{31 P} \mathrm{NMR}\left(-40^{\circ} \mathrm{C}, \mathrm{CDCl}_{3}\right) \delta 50.2\left(\mathrm{~d}, J_{\mathrm{P}-\mathrm{F}}=47.0 \mathrm{~Hz}\right)$; MS (FAB) $m / z$ 856.5 $\left(\mathrm{M}^{+}\right), 837.5\left(\mathbf{M}^{+}-F\right), 792.4\left(\mathrm{M}^{+}-\mathrm{F}, \mathrm{CH}_{2} \mathrm{OMe}\right)$, $629.7\left(\mathrm{M}^{+}-\mathrm{C}_{2} \mathrm{FPhCH}_{2} \mathrm{OMe}\right), 429.0\left(\mathrm{M}^{+}-\mathrm{PPh}_{3}, \mathrm{C}_{2} \mathrm{FPhCH}_{2} \mathrm{OMe}\right)$. Only one of the $E, Z$-isomers was obtained, and the spectroscopic data are not sufficient to identify the geometry.

(15) (a) Clark, J. H. Chem. Rev. 1980, 80, 429 and references therein. (b) Jakobson, G. G.; Akmentova, N. E. Synthesis 1983, 169. (c) Clark, J. H. J. Chem. Soc., Chem. Commun. 1978, 789. (d) Landini, D.; Maia, A.; Rampoldi, A. J. Org. Chem. 1989, 54, 328.

(16) (a) Chi, D. Y.; Kilbourn, M. R.; Katzenellenbogen, J. A. J. Org. Chem. 1987, 52, 658. (b) Haas, A.; Lieb, M. Chimia 1985, 39, 134. (c) Cox, D. P. Terpinsky, J. Lawrymowicz, W.J. Org. Chem. 1984, 49, 3216 (17) Spectroscopic data for $2 \mathrm{~d}:{ }^{1} \mathrm{H}$ NMR $\left(25^{\circ} \mathrm{C}, \mathrm{CD}_{3} \mathrm{CN}\right) \delta 7.49-6.58$ $(\mathrm{Ph}), 5.30(\mathrm{~s}, 1 \mathrm{H}, \mathrm{CH}), 5.29(\mathrm{~s}, 5 \mathrm{H}, \mathrm{Cp})$; $^{13} \mathrm{C} \mathrm{NMR}\left(25^{\circ} \mathrm{C}, \mathrm{CD}_{3} \mathrm{CN}\right) \delta 340.3$ $\left(\mathrm{t}, J_{\mathrm{C}-\mathrm{P}}=16.5 \mathrm{~Hz}, \mathrm{C}_{\alpha}\right), 135.9-128.8(\mathrm{Ph} ' \mathrm{~s}), 125.3(\mathrm{CN}), 122.6\left(\mathrm{C}_{\beta}\right), 96.2$ (Cp), $60.1\left(\mathrm{CPh}_{3}\right), 36.0(\mathrm{CH}){ }^{31} \mathrm{P}$ NMR $\left(25^{\circ} \mathrm{C}, \mathrm{CD}_{3} \mathrm{CN}\right) \delta 41.3,38.6$ (d, $\left.J_{\mathrm{P}-\mathrm{P}}=26.5 \mathrm{~Hz}\right) ; \mathrm{MS}(20 \mathrm{eV}) \mathrm{m} / z 1074\left(\mathrm{M}^{+}-\mathrm{PF}_{6}\right), 832\left(\mathrm{M}^{+}-\mathrm{PF}_{6}, \mathrm{CPh}_{3}\right)$, $569\left(\mathrm{M}^{+}-\mathrm{PF}_{6}, \mathrm{CPh}_{3}, \mathrm{PPh}_{3}\right)$. 
$(n-\mathrm{Bu})_{4} \mathrm{NF}$ ( $1 \mathrm{M}$ in THF) also affords the cyclopropenyl complex $\mathrm{Cp}\left(\mathrm{PPh}_{3}\right){ }_{2} \mathrm{RuC}=\mathrm{C}(\mathrm{Ph}) \mathrm{C}\left(\mathrm{CPh}_{3}\right) \mathrm{CN} \quad\left(3 \mathrm{~d}^{\prime 18}\right.$ see Scheme 1). The yield is only $35 \%$ in this reaction. The 31P NMR spectra of $2 d$ and $3 \mathbf{d}$ both give the expected $A B$ pattern because of the chiral carbon that makes the two phosphine ligands inequivalent. The vinylidene ligand of 2, with two different substituents, is a two-dimensional chiral simplex. ${ }^{19}$ The complex is considered as having a plane of chirality. We are currently investigating possible asymmetric induction by using the chiral phosphine

(18) Spectroscopic data for 3d: ${ }^{1} \mathrm{H}$ NMR $\left(25^{\circ} \mathrm{C}, \mathrm{CDCl}_{3}\right) \delta 7.79-5.47$ (Ph), 4.29 (s, 5H, Cp); ${ }^{13} \mathrm{C} \mathrm{NMR}\left(25^{\circ} \mathrm{C}, \mathrm{CDCl}_{3}\right) \delta 142.0-125.0$ (Ph's), 121.1 (CN), $84.6(\mathrm{Cp}), 62.1\left(\mathrm{CPh}_{3}\right), 37.5(\mathrm{CCN})$; $31 \mathrm{P}$ NMR $\left(25^{\circ} \mathrm{C}, \mathrm{CDCl}_{3}\right) 47.0$ $46.7\left(\mathrm{~d}, J_{\mathrm{P}-\mathrm{P}}=35.6 \mathrm{~Hz}\right) ; \mathrm{MS}(20 \mathrm{eV}) \mathrm{m} / \mathrm{z} 1074\left(\mathrm{M}^{+}\right), 811\left(\mathrm{M}^{+}-\mathrm{PPh}_{3}\right)$ $691\left(\mathrm{M}^{+}-\mathrm{C}_{3} \mathrm{Ph}(\mathrm{CN}) \mathrm{CPh}_{3}\right)$.

(19) Prelog, V.; Helmchen, G. Angew. Chem. 1982, 94, 614 ligand. ${ }^{20}$ Also, experiments to test the generality of this kind of reaction, particularly for analogous molybdenum complexes, are in progress.

Acknowledgment. We are grateful for support of this work by the National Science Council, Taiwan, Republic of China.

Supplementary Material Available: Details of the structural determination for complex 3a, including a figure giving an additional view of the structure and tables of crystal and intensity collection data, positional and anisotropic thermal parameters, and all of bond distances and angles ( 8 pages). Ordering information is given on any current masthead page.

OM940130E

(20) Consiglio, G.; Morandini, F. Chem. Rev. 1987, 87, 761. 